\title{
Application of the CardioCel bovine pericardial patch - a preliminary report
}

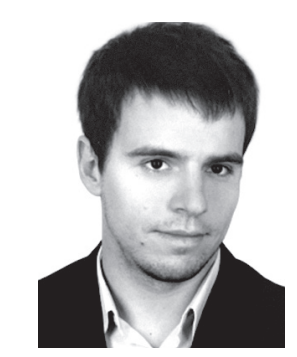

\author{
Michał Sobieraj ${ }^{1}$, Edyta Cudak ${ }^{2}$, Wojciech Mrówczyński ${ }^{1}$, Tomasz K. Nałęcz ${ }^{3}$, Przemysław Westerski ${ }^{1}$, \\ Michał Wojtalik ${ }^{1}$ \\ ${ }^{1}$ Department of Cardio-Thoracic Surgery, Department of Pediatric Cardiac Surgery, Poznan University \\ of Medical Sciences, Poznan, Poland \\ ${ }^{2}$ Nursing Department of Anesthesiology and Intensive Care, Poznan University of Medical Sciences, Poznan, Poland \\ ${ }^{3} \mathrm{~K}$. Jonscher Clinical Hospital, Poznan University of Medical Sciences, Poznan, Poland
}

Kardiochirurgia i Torakochirurgia Polska 2016; 13 (3): 210-212

\begin{abstract}
Introduction: Animal pericardial patches are widely used in adult and pediatric cardiac surgery. A search is ongoing for a new material with optimal surgical properties that will reduce intraoperative bleeding and the occurrence of restenosis, calcification, and pseudoaneurysms in long-term observation. One product of interest is the CardioCel bovine pericardial patch.

Aim: Evaluation of the short-term results of CardioCel bovine pericardial patch implantation during pediatric cardiac surgery. Material and methods: The study included 8 patients who underwent surgical correction of congenital cardiac defects between January 2015 and February 2016. Pericardial patches were used to repair supravalvular aortic stenosis and reconstruct the aortic arch and pulmonary arteries. The age of the patients ranged from 10 days to 14 years.

Results: There were no hospital deaths. The new material exhibited satisfactory durability and elasticity during surgery, facilitating optimal adaptation of the patch to the patient's tissues. No significant bleeding was reported from the suture site. The median duration of follow-up was 58 days. During the follow-up, there were no symptoms of pseudoaneurysm formation, patch thickening, or calcification in the areas where the pericardial patches were implanted. No clinical or laboratory symptoms of infection were observed in locations where the new material was applied.

Conclusions: Satisfactory surgical properties of the patch were observed intraoperatively. Positive results using the new pericardial patch were obtained in short-term follow-up.

Key words: pericardial patch, aortic arch, stenosis.
\end{abstract}

\section{Introduction}

Pericardial patches made from animal tissue have a wide range of applications in various fields of surgery

\section{Streszczenie}

Wstęp: Zwierzęce łaty osierdziowe znajdują obecnie szerokie zastosowanie w kardiochirurgii dorosłych oraz dzieci. Trwa poszukiwanie materiału, który będzie cechował się optymalnymi właściwościami chirurgicznymi, ograniczy krwawienia śródoperacyjne oraz powstawanie ponownych zwężeń, zwapnień i pseudotętniaków w okresie odległym. Jednym z interesujących produktów jest wołowa łata osierdziowa CardioCel.

Cel: Wstępna ocena wykorzystania łaty osierdziowej CardioCel u pacjentów pediatrycznych poddanych korekcji wrodzonej wady serca wymagającej zastosowania implantu do poszerzenia operowanych struktur.

Materiał i metody: Badaniem objęto 8 pacjentów, którzy zostali poddani korekcji wrodzonej wady serca od stycznia 2015 do lutego 2016 r. Łatę wykorzystano do plastyki zwężenia nadzastawkowego aorty, plastyki łuku aorty oraz tętnic płucnych. Wiek pacjentów wynosił od 10 dni do 14 lat.

Wyniki: Nie odnotowano zgonów wewnątrzszpitalnych. Śródoperacyjnie stwierdzono zadowalającą wytrzymałość oraz elastyczność nowego materiału, co umożliwiało jego optymalne dopasowanie do tkanek natywnych. Podczas operacji nie obserwowano istotnego krwawienia z miejsc wszywania łaty. Mediana czasu obserwacji wynosiła 58 dni. Podczas wstępnych obserwacji nie stwierdzono tętniaków, pogrubienia łaty oraz procesu kalcyfikacji w miejscach wszycia implantu u wszystkich pacjentów. Nie odnotowano klinicznych oraz laboratoryjnych objawów infekcji mogącej mieć związek z implantacją łaty. Wnioski: Śródoperacyjnie zaobserwowano zadowalające właściwości chirurgiczne łaty. Wykazano pozytywne wyniki z wykorzystaniem nowego implantu podczas wczesnych obserwacji. Słowa kluczowe: łata osierdziowa, łuk aorty, zwężenie.

including vascular and general surgery, urology, and cardiac surgery. Some noteworthy applications of pericardial patches in cardiac surgery include the reconstruction of the 
aorta and pulmonary vessels, closure of interatrial defects, closure of interventricular defects, and reconstruction of atrioventricular valves [1-3]. Their advantages include the ease with which they can be obtained and used as well as the fact that they are associated with less intraoperative bleeding from the suture line in comparison with artificial materials $[1,4,5]$. The disadvantages include the development of secondary stenosis at the suture site (resulting from fibrosis and calcification), the possibility of aneurysm development, and, often, high prices of the products [5]. Many implants are available on the market: biointegral pericardial patches, the bovine collagen membrane Tutopatch, and the equine pericardial patch from Edwards Lifesciences. One of the newest products on the market is the bovine pericardial patch CardioCel, distinguished from the other available products by the fact that glutaraldehyde is not used during its processing.

\section{Aim}

The aim of this report is to provide preliminary analysis of the effects of the CardioCel pericardial patch in pediatric patients undergoing congenital heart defect correction requiring the use of the implant.

\section{Material and methods}

The study included 8 patients who underwent repair of congenital heart defects under extracorporeal circulation and were implanted with CardioCel pericardial patches during the period between January 2015 and February 2016. The age of the patients ranged from 10 days to 14 years. The patients underwent three types of procedures: aortic arch reconstruction, repair of supravalvular aortic stenosis, and pulmonary artery reconstruction. The demographic details of the patients and the types of procedures are presented in Table I.

The study employed data originating from the patients' medical records, operative protocols, and the local hospital database, as well as results of echocardiography, angiography, and computed tomography (angio-CT).

\section{The patch}

Intraoperatively, the patch required no further preparation. After being taken out of the container, it was ready to be used.

Its mechanical endurance was found to be satisfactory: the sutures held without rupturing the graft, and the implant's elasticity facilitated optimal adaptation of the patch to the native tissue. No significant bleeding from the suture site was observed during the procedures. Perioperatively, there were no clinical or laboratory signs of infection that could be associated with the patch implantation.

\section{Results}

There was no in-hospital mortality; all the patients included in the study were alive at the conclusion of the follow-up. The length of hospital stay ranged from 8 to 58 days (median: 15 days). The observed complications included: pneumonia in 2 patients, vocal cord paralysis in 2 patients, and paralysis of the left diaphragmatic dome in 1 patient (which necessitated a plication procedure during the same hospitalization).

The postoperative follow-up lasted from 14 to 219 days (median: 58 days). During this time, no aneurysms, patch thickening, or calcification at the suture site occurred in any of the patients. There were no clinical or laboratory signs of infection that could be associated with the patch implantation.

In 2 patients, stenosis was observed at the suture site. In the patient with aortic arch hypoplasia, atrioventricular septal defect, and Down's syndrome, the stenosis at the suture site was observed from the first days after the procedure performed to widen the aortic arch. Follow-up transthoracic echocardiography revealed no signs of coarctation at the suture site; the mean flow velocity in the aortic arch was $3.0 \mathrm{~m} / \mathrm{s}$, and the flow in the abdominal aorta corresponded with the arterial flow. In the patient who underwent repair of supravalvular stenosis of the ascending aorta and reconstruction of the pulmonary trunk and right pulmonary artery, increasing stenosis is observed at both

Tab. I. Characteristics of patients, types of procedures, and application of pericardial patches

\begin{tabular}{|c|c|c|c|c|c|}
\hline No. & $\begin{array}{l}\text { Gender } \\
\text { (M/F) }\end{array}$ & $\begin{array}{l}\text { Age } \\
\text { [days] }\end{array}$ & $\begin{array}{l}\text { Body mass } \\
{[\mathrm{kg}]}\end{array}$ & Diagnosis & $\begin{array}{l}\text { Type of procedure with pericardial } \\
\text { patch implantation }\end{array}$ \\
\hline 1 & $\mathrm{~F}$ & 50 & 3 & HAA, VSD, MV stenosis & HAA correction (patch) + VSD correction + TV plasty \\
\hline 2 & M & 55 & 2.9 & HAA, VSD & HAA correction (patch) + VSD correction \\
\hline 3 & M & 50 & 3.5 & HAA, aberrant LSCA & HAA correction $($ patch) + aberrant LSCA correction \\
\hline 4 & $\mathrm{~F}$ & 5088 & 47 & VSD, post PAB, LPA stenosis & LPA and PA plasty (patch), VSD correction, TV plasty \\
\hline 5 & M & 10 & 2.9 & ToF, LPA stenosis & Central anastomosis, LPA plasty (patch) \\
\hline 6 & M & 4620 & 62 & Supravalvular AS & Plasty of supravalvular AS (patch) \\
\hline 7 & M & 201 & 7.9 & $\begin{array}{l}\text { Supravalvular AS, supravalvular PS, } \\
\text { RPA stenosis, Williams syndrome }\end{array}$ & $\begin{array}{c}\text { Plasty (patch) of supravalvular AS, supravalvular PS, } \\
\text { and RPA }\end{array}$ \\
\hline 8 & $\mathrm{~F}$ & 38 & 3 & HAA, AVSD, Down syndrome & HAA correction (patch) + PAB \\
\hline
\end{tabular}

HAA - hypoplastic aortic arch, VSD - ventricular septal defect, PAB - pulmonary artery banding, LPA - left pulmonary artery, RPA - right pulmonary artery, TV - tricuspid valve, AS - aortic stenosis, ToF - tetralogy of Fallot, AVSD - atrioventricular septal defect, PS - pulmonary stenosis, LSCA - left subclavian artery 
suture sites (MVF $4.5 \mathrm{~m} / \mathrm{s}$ in the ascending aorta and MVF $3.3 \mathrm{~m} / \mathrm{s}$ in the pulmonary vessels). No significant clinical consequences of the stenosis were observed in either of the patients; both remain under out-patient observation.

\section{Discussion}

The use of bovine pericardium has many applications in both adult and pediatric cardiac surgery [1-4]. Many cardiac surgeons use it, appreciating the wide selection of implants and their potential advantages. Currently, a search is ongoing for a material that will have optimal surgical properties and will limit the occurrence of complications such as secondary stenosis, intraoperative bleeding, infections at the suture site, and aneurysm development [5-7].

This report presents preliminary experiences with the use of a next-generation acellular bovine pericardial patch - CardioCel. According to the manufacturer, the patch can be used for intracardiac defect corrections, atrioventricular valve reconstruction, or vascular repair. Neethling et al. demonstrated satisfactory results of using the patch for correcting intracardiac defects and performing vascular reconstruction in a group of 30 children [8]. Favorable properties of the patch as a potential material for valve reconstructions have been demonstrated in an animal model [9]. Mazzitelli et al. were the first to report the use of CardioCel for reconstructing the aortic valve in 3 pediatric patients, with good results [10]. The abovementioned reports present successful preliminary results, but are limited by small sample sizes and short follow-up periods.

\section{Conclusions}

In our material, the patch was employed to reconstruct the aorta and pulmonary arteries. Satisfactory properties of the patch were observed intraoperatively. The use of the patch was associated with positive results according to the preliminary observations made at our center; however, pre- cise analysis requires studies on larger patient samples and with longer periods of follow-up.

\section{Disclosure}

Authors report no conflict of interest.

\section{References}

1. Us MH, Sungun M, Sanioglu S, Pocan S, Cebeci BS, Ogus T, Ucak A, Guler A. A retrospective comparison of bovine pericardium and polytetrafluoroethylene patch for closure of ventricular septal defects. J Int Med Res 2004; 32: 218-221.

2. David TE. The use of pericardium in acquired heart disease: a review article. J Heart Valve Dis 1998; 7: 13-18.

3. Yaliniz H, Salih OK, Atalay A, Keklik V, Gocen U, Topcuoglu MS, Guzel Y, Basturk Y, Aslan M, Erdem S, Poyrazoglu H. Short- and mid-term results of xenograft-bovine pericardial patch in the repair of intracardiac defects: final results of a single-centre study. Cardiol Young 2014; 24: 510-514.

4. Crawford FA Jr, Sade RM, Spinale F. Bovine pericardium for correction of congenital heart defects. Ann Thorac Surg 1986; 41: 602-605.

5. Li X, Guo Y, Ziegler KR, Model LS, Eghbalieh SD, Brenes RA, Kim ST, Shu C, Dardik A. Current usage and future directions for the bovine pericardial patch. Ann Vasc Surg 2011; 25: 561-568.

6. Chang Y, Lai PH, Wang CC, Chen SC, Chang WC, Sung HW. Mesothelium regeneration on acellular bovine pericardia loaded with an angiogenic agent (ginsenoside Rg1) successfully reduces postsurgical pericardial adhesions. J Thorac Cardiovasc Surg 2006; 132: 867-874.

7. Santibanez-Salgado JA, Olmos-Zuniga JR, Perez-Lopez M, Aboitiz-Rivera C, Gaxiola-Gaxiola M, Jasso-Victoria R, Sotres-Vega A, Baltazares-Lipp M, PérezCovarrubias D, Villalba-Caloca J. Lyophilized glutaraldehyde-preserved bovine pericardium for experimental atrial septal defect closure. Eur Cell Mater 2010; 19: 158-165.

8. Neethling WM, Strange G, Firth L, Smit FE. Evaluation of a tissue-engineered bovine pericardial patch in paediatric patients with congenital cardiac anomalies: initial experience with the ADAPT-treated CardioCel(R) patch. Interact Cardiovasc Thorac Surg 2013; 17: 698-702.

9. Brizard CP, Brink J, Horton SB, Edwards GA, Galati JC, Neethling WM. New engineering treatment of bovine pericardium confers outstanding resistance to calcification in mitral and pulmonary implantations in a juvenile sheep model. J Thorac Cardiovasc Surg 2014; 148: 3194-3201.

10. Mazzitelli D, Nobauer C, Rankin JS, Vogt M, Lange R, Schreiber C. Complete aortic valve Cusp replacement in the pediatric population using tissue-engineered bovine pericardium. Ann Thorac Surg 2015; 100: 1923-1925. 